\title{
Statistika u nastavi matematike $u$ osnovnoj školi - trenutni status i promjene koje donosi kurikularna reforma
}

\author{
Ivan Nad
}

\section{Sažetak}

Razvoj kritičkog i analitičkog mišljenja je jedan od odgojno obrazovnih ciljeva poučavanja matematike. Statistika je pogodan alat za pomoć pri ostvarenju tog cilja no nastavni plan i program matematike za osnovnu školu predviđa prvi susret sa statistikom tek u sedmom razredu osnovne škole. Anketa provedena među učiteljima matematike pokazala je da često vrlo malo pažnje pridaju poučavanju statistike, ponajviše zbog velikog broja ostalih sadržaja koje moraju odraditi s učenicima. Kurikularna reforma donijela je određene promjene i poučavanje statistike je raslojeno po svim razredima osnovne škole, od piktograma u prvom razredu do analitičkog rješavanja složenijih problema koristeći statistiku u osmom razredu. U članku se raspravlja o nekim problemima, predlažu rješenja, detaljnije/dodatne razrade, ali i dodatni (prošireni) sadržaji te prijedlozi za njihovo ostvarivanje.

Ključni pojmovi: statistika, matematika, kurikularna reforma

\section{Zašto podučavati učenike statistiku?}

Za početak, statistika je, prema „Odluci o donošenju kurikuluma za nastavni predmet Matematike za osnovne škole i gimnazije u Republici Hr- 
vatskoj" [1] (od 14. siječnja 2019.) dio jedne od pet domena predmeta matematika (naziv domene: Podatci,statistika $i$ vjerojatnost).

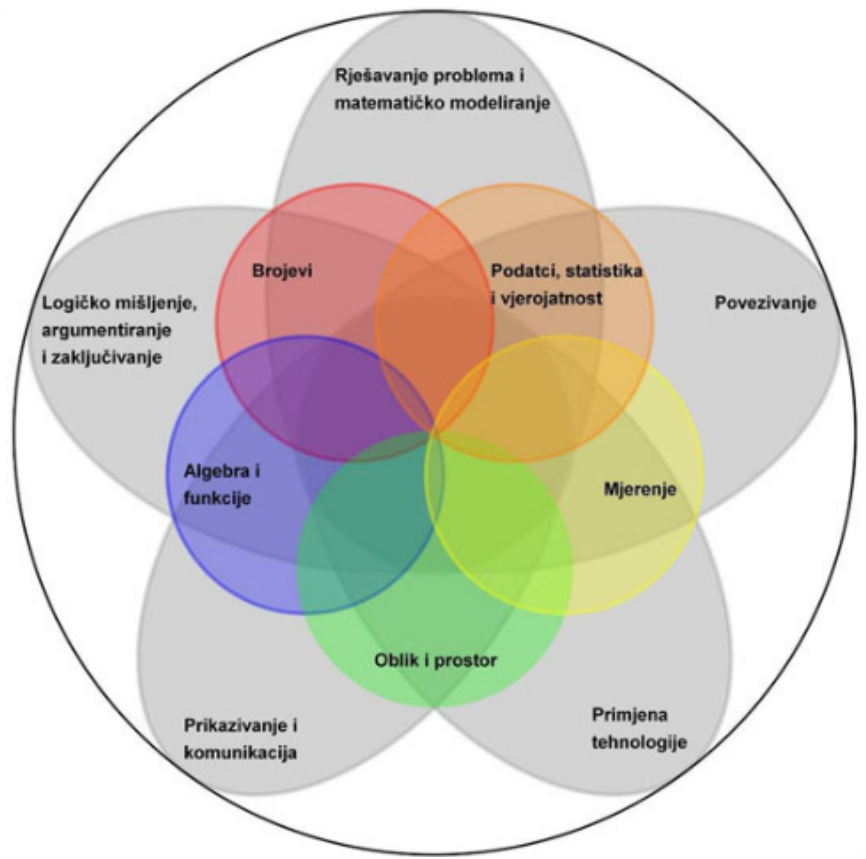

Slika 1: Matematički procesi i domene kurikuluma nastavnoga predmeta Matematika

Nadalje, jedan od najvažnijih razloga za poučavanje statistike, ako ne i najvažniji, je poticanje i razvoj kritičkog (refleksivnog) promišljanja i povezivanja kod učenika, a koje je, prema prethodno spomenutoj Odluci [1, jedan od odgojno-obrazovnih ciljeva učenja i poučavanja predmeta Matematika u osnovnoj školi.

Definicije kritičkog mišljenja se razlikuju od autora do autora, a najprihvaćenija je ona APA-e (American Philosophical Association) koja govori da je kritičko mišljenje svrhovito samoregulirano prosuđivanje čiji je rezultat analiza, evaluacija i zaključivanje, kao i objašnjenje dokaznih, konceptualnih, metodoloških, kriterijskih ili kontekstualnih razmatranja na kojima se temelji prosuđivanje.

Koliko je važno u Hrvatskoj dodatno staviti naglasak na poučavanje koje potiče kritičko promišljanje i povezivanje, dovoljno govori istraživanje koje je 2018. proveo World Economic Forum [2]. Ocjene su u istraživanju bile na skali od 1 do 7 , gdje 1 znači frontalni pristup poučavanju, učitelj u glavnoj ulozi, fokus na memoriranje podataka, a 7 poučavanje koje 
potiče individualno, kreativno i kritično promišljanje. Hrvatska je postigla ocjenu 2.3 što je očit znak da su u sistemu poučavanja nužne promjene (najveću ocjenu u istraživanju su imale SAD 5.7, a najnižu Angola 1.9).

Jedan od rezultata naglaska na kritičko promišljanje i povezivanje u obrazovanju su onda i informirani i educirani potrošači koji znaju kritički procijeniti podatke koji im se prikazuju, a pogotovo prepoznati manipulacije podatcima ili njihove krive interpretacije.

Primjeri toga su sljedeći grafički prikazi koji bi, bez razvijenog kritičkog promišljanja, lako mogli dovesti do krivih zaključaka.

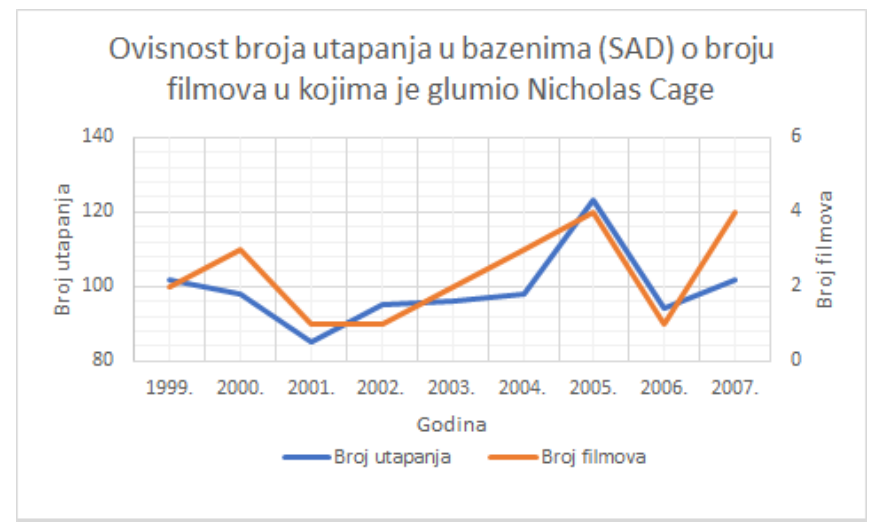

Slika 2: Ovisnost broja utapanja u bazenima (SAD) o broju filmova u kojima je glumio Nicholas Cage

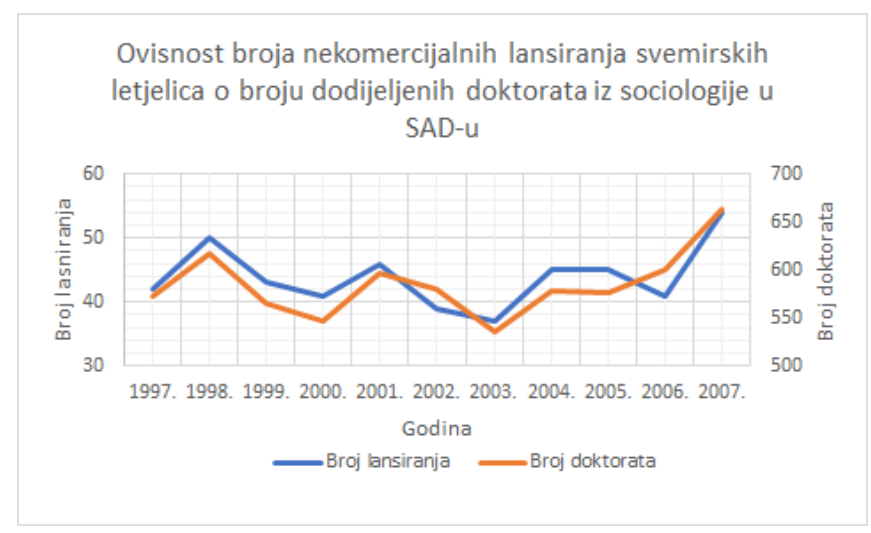

Slika 3: Ovisnost broja nekomercijalnih lansiranja svemirskih letjelica o broju doktora iz sociologije 


\section{Trenutni status statistike u osnovnim ško- lama}

U „Nacionalnom okvirnom kurikulumu” (krace NOK-u) [3] se definiraju očekivana učenička postignuća po obrazovnim ciklusima kroz matematičke procese i matematičke koncepte. Od 6 matematičkih koncepata, statistika se kroz koncept Podatci provlači kroz sva 4 ciklusa (od predškolskog odgoja pa sve do srednjoškolskog obrazovanja).

Očekivana učenička postignuća su pisana u futuru i, zaključno s krajem osnovnoškolskog obrazovanja, tj. trećeg ciklusa su:

„Učenici će:

- prikupiti, klasificirati i organizirati podatke te ih na prikladan način, pomoću računala $i$ bez njega, prikazati sustavnom listom, tablicom, tablicom frekvencija, linijskim, stupčastim i kružnim dijagramom, grafikonom, „brkatom kutijom” („box and whiskers” dijagram) $i$ grafom

- pročitati, tumačiti i analizirati podatke prikazane na različite načine

- odrediti i primijeniti frekvenciju i relativnu frekvenciju za dane podatke te aritmetičku sredinu, medijan, kvartile, mod, raspon $i$ interkvartilni raspon niza numeričkih podataka" 3.

No, situacija je najčešće posve drugačija. Naime, po nastavnom planu i programu 4] koji je trenutno na snazi (i koji će biti dok kurikularna reforma ne zahvati sve razrede), o statistici se nažalost najčešće govori (a i jedino spominje unutar nastavnog plana i programa) tek u sedmom razredu unutar teme „Prikazivanje i analiza podataka”. Sve što o danoj temi u nastavnom planu i programu piše je sljedeće:

„Ključni pojmovi: obilježje skupa objekata, frekvencija i relativna frekvencija, tablični prikaz, stupčasti dijagram, kružni dijagram.

Obrazovna postignuća: prepoznati obilježje skupa objekata, odredivati vrijednosti tog obilježja; prikazivati prikupljene podatke o tom obilježju s pomoću tablice frekvencija i relativnih frekvencija te grafički $s$ pomoću stupčastoga dijagrama $i$ kružnoga dijagrama; izračunavati aritmetičku sredinu te interpretirati dobivene podatke."

Prethodne navode o zapostavljenosti statistike potvrđuje i anketni upitnik 8] koji sam od 5. 8. 2019. do 8. 8. 2019. proveo među 70 učitelja matematike u predmetnoj nastavi (33 ispitanika do 10 godina radnog staža u zanimanju učitelj matematike u osnovnoj školi, 23 ispitanika između 10 i 20 godina staža, 11 ispitanika između 20 i 30 godina staža, a 3 ispitanika sa po više od 30 godina radnog staža). U njemu je $71.4 \%$ ispitanika izjavilo da statistiku s učenicima obrađuje tek u sedmom razredu. Nadalje, $55.7 \%$ ispitanika se strogo drži plana i programa i odradi s 
učenicima tek predviđeno njime (40\% učitelja radi više od predviđenog). Što se broja sati nastave tiče, najviše ispitanika, njih $64.3 \%$ statistiku radi pet do deset školskih sati, a $22.9 \%$ više od 10 sati. Također, čak $85.7 \%$ ispitanika je izjavilo da bi statistika trebala biti zastupljenija $\mathrm{u}$ nastavi matematike.

\section{Statistika i kurikularna reforma}

Prema domeni „Podatci, statistika i vjerojatnost” iz Odluke [1], statistika ima svoje mjesto u nastavi matematike i u novoj kurikularnoj reformi:

„Domena Podatci, statistika i vjerojatnost bavi se prikupljanjem, razvrstavanjem, obradom, analizom $i$ prikazivanjem podataka $u$ odgovarajućemu obliku. Podatke dane grafičkim ili nekim drugim prikazom treba znati očitati te ih ispravno protumačiti $i$ upotrijebiti. Sve se to postiže koristeći se jezikom statistike. Ona podrazumijeva uporabu matematičkoga aparata kojim se računaju mjere srednje vrijednosti, mjere raspršenja, mjere položaja i korelacije podataka." 1]

Odgojno-obrazovni ishodi su u Odluci [1] pisani na razini usvojenosti „dobar" na kraju razreda, a statistika je raslojena kroz svih osam razreda osnovne škole kako slijedi:

\begin{tabular}{|c|l|}
\hline Razred & \multicolumn{1}{|c|}{ Ishod (učenik/ca:) } \\
\hline Prvi & - čita i prikazuje podatke piktogramima \\
\hline Drugi & $\begin{array}{l}\text {-prikupljene podatke prikazuje jednostavnim tabli- } \\
\text { cama i piktogramima }\end{array}$ \\
\hline Treći & $\begin{array}{l}\text {-prikazuje podatke u tablicama i dijagramima } \\
\text { (stupčastim) }\end{array}$ \\
\hline Cetvrti & $\begin{array}{l}\text {-provodi jednostavno istraživanje u kojemu podatke } \\
\text { razvrstava prema zadanome kriteriju }\end{array}$ \\
\hline Peti & $\begin{array}{l}\text {-tumači prikaz podataka tablicama, slikama, listama } \\
\text { te različitim grafovima i dijagramima }\end{array}$ \\
\hline Šsti & $\begin{array}{l}\text {-određuje frekvencije razvrstanih podataka potrebne } \\
\text { za grafički prikaz } \\
\text {-prikupljene podatke prikazuje linijskim dijagramom } \\
\text { frekvencija }\end{array}$ \\
\hline Sedmi & $\begin{array}{l}\text {-određuje relativne frekvencije razvrstanih podataka } \\
\text { potrebne za grafički prikaz } \\
\text {-prikupljene podatke prikazuje stupčastim dijagram- } \\
\text { om relativnih frekvencija i tumači prikaz }\end{array}$ \\
\hline Osmi & - \\
\hline
\end{tabular}

Tablica 1: Odgojno-obrazovni ishodi iz Odluke [1] vezani uz statistiku 
U osmom razredu se statistika koristi kao pomoćni alat u realizaciji drugih ishoda, ponajviše vezanih uz kamatni račun (za koji nije predviđeno da se uvježbava tehnika računanja, nego učenikovo logičko mišljenje i sposobnost analize problema).

Ishodi ne samo da su u Odluci [1] razrađeni detaljnije od pukog ispisa, nego su dani i prijedlozi kako te ishode ostvariti (primjeri pitanja za učenike, zadataka i slično), ali i mogući prošireni sadržaji ako učitelj ocijeni da sa svojim učenicima može ostvariti i više.

Ispitanici, u anketnom upitniku 8] koji sam proveo, također pozdravljaju promjene što dokazuje podatak da se njih čak $87.1 \%$ planira više posvetiti statistici u sklopu promjena koje donosi Odluka [1].

Da je veća implementacija statistike opravdana i ne prezahtjevna za učenike i u razrednoj nastavi (kao što predlaže Odluka 1]), govore i rezultati TIMSS (Trends in International Mathematics and Science Study) istraživanja. TIMSS istraživanje provodi se svake četiri godine na učenicima četvrtih i osmih razreda, počevši od 1995., a u Hrvatskoj je provedeno 2011. i 2015. godine na učenicima četvrtih razreda. Istraživanje ima tri sadržajne domene u četvrtom razredu, od kojih je jedna „Prikaz podataka”, a u osmom razredu četiri domene od kojih je jedna "Podaci $i$ vjerojatnost".

U Hrvatskoj je 2015. godine istraživanju pristupilo 4000 učenika četvrtih razreda iz 163 osnovne škole (na svjetskoj razini više od 600000 učenika). Rezultati istraživanja se izražavaju kao nacionalni prosjek, a ukupni prosječni rezultat hrvatskih učenika u matematici je 2015. godine bio 502 boda (svjetski prosjek 500 bodova), dok ljestvicu predvode singapurski učenici s prosjekom od 618 bodova. Što se sadržajnih domena tiče, naši učenici su najbolji rezultati imali u domeni „Geometrijski oblici i mjerenje” (512 bodova), a najlošiji, između ostalog, u domeni „Prikaz podataka" (498 bodova). [6]

\section{Neki od problema}

Učenike prije svega treba motivirati njima bliskim primjerima i aktivnostima ili malim istraživačkim projektima, pogotovo u ranijoj dobi. Dobro je korelirati s ostalim predmetima u školi (pogotovo je to moguće, kako su sami učitelji izjavili u anketnom upitniku, s geografijom, prirodom/biologijom i povijesti).

Godine 2006. su Benček, Marenić [5] provele istraživanje na 374 učenika osmih razreda, u deset osnovnih škola u gradu Zagrebu. Rezultati tog istraživanja sugeriraju da su nužne određene promjene.

Ponajviše je to bitno ako se pogledaju neke brojke iz samog istraživanja: 
- $72 \%$ učenika kaže da rad njihovih učitelja matematike utječe i na rad njih samih

- $81.6 \%$ učenika se na nastavi matematike dosađuje

- tek nešto više od $15 \%$ učenika uči matematiku zbog zanimljivosti sadržaja.

Zato je, uz korelaciju s ostalim predmetima, bitna i korelacija s učenicima bliskim primjerima iz njihovog svakodnevnog svijeta. Učenike više zanimaju mala istraživanja vezana uz, primjerice, društvene mreže, računalne igre, sport, tehnologiju, njih same i uže društvo u kojem se nalaze nego istraživanja vezana uz, primjerice, natalitet, mortalitet, padaline na nekom području, stanovništvo po popisima stanovništva i slično.

Također, potrebno je više poticati upotrebu IKT-a u nastavi. Rezultati anketnog upitnika 8 kažu da $68.6 \%$ učenika koristi IKT za učenje statistike, bilo kod kuće ili u školi, a čak $87.1 \%$ učitelja matematike koristi IKT za podučavanje statistike. Poboljšanja su moguća u dijelu korištenja statistike izvan matematike, kroz projekte, suradnju s ostalim predmetima i slično, pogotovo ako uzmemo u obzir da je tek $61.4 \%$ učitelja izjavilo da su njihovi učenici, kroz različite projekte u kojima su sudjelovali, koristilo statistiku (više od pukog računanja aritmetičke sredine).

Sljedeći problem je sama educiranost učitelja, kako matematike, tako i onih razredne nastave. Posebice se problem javlja kod učitelja razredne nastave, pogotovo ako pogledamo rezultate istraživanja koje je u sklopu diplomskog rada [7] 2018. godine A. Sakač provela na 49 od 55 studenata četvrte godine Učiteljskog fakulteta, odsjeka Čakovec. Istraživanje se sastojalo od dva kruga anketnih upitnika i radionice o vrstama zadataka iz statistike primjerenima za razrednu nastavu. Istraživanje je ukazalo na nesklad između Odluke [1] i formalnog obrazovanja koje studenti primaju na fakultetu. Iako se $89.8 \%$ studenata dotad već susrelo sa statistikom kroz svoje formalno obrazovanje, većina njih je kroz svoje dotadašnje obrazovanje podatke prikazivala stupčastim dijagramom $(89,8 \%)$, koji je po Odluci 1 1 predviđen za obradu u trećem razredu, te kružnim (85.7\%) i linijskim (73.5\%), a koji nisu predviđeni za obradu u razrednoj nastavi. Poražavajuća činjenica je da je tek $22.5 \%$ njih koristilo slikovne dijagrame (nije se tražilo od njih specificirati kroz fakultetsko ili ranije obrazovanje), a što bi oni trebali poučavati učenike od 1. razreda osnovne škole. Studenti nisu niti informirani o prednostima i pozitivnim utjecajima poučavanja statistike pa je tako njih $57.1 \%$ (prije radionice) izjavilo da učenici razredne nastave ne bi uopće trebali usvajati sadržaje iz statistike. Također, prije te iste radionice, $44.9 \%$ studenata je izjavilo da se ne smatraju kompetentima podučavati sadržaje iz statistike 
u razrednoj nastavi. Važno je napomenuti da je radionica za studente provedena samo kao dio istraživanja u sklopu diplomskog rada i nije dio redovnog fakultetskog obrazovanja tih studenata.

To ukazuje na pretjeranu žurbu s donošenjem i primjenom novih kurikuluma te nesklad s fakultetskim obrazovanjem jer se fakulteti koji obrazuju učitelje nisu imali vremena prilagoditi i uvrstiti ne samo statistiku, nego i ostale nove teme planirane novim kurikulumom u svoj nastavni plan i program. Pogotovo je to problematično za nove generacije učitelja koje nisu imale priliku biti educirane kao trenutno zaposleni učitelji, ali se problem javlja i kod učitelja koji, u trenutku održavanja edukacija (bilo u virtualnim učionicama ili fizičkim prisustvom), iz bilo kojeg razloga nisu bili zaposleni u školi pa su edukaciji mogli pristupiti uz prethodnu dozvolu Ministarstva znanosti i obrazovanja, a što mnogi od učitelja zapravo niti ne znaju.

No, nisu niti svi učitelji, koji su trenutno zaposleni u školama, educirani. Kako nigdje izrijekom nije bilo navedeno da su edukacije u virtualnim učionicama obavezne za učitelje, tako niti svi učitelji koji su to mogli, iz različitih razloga nisu pristupili edukaciji. Također, te su edukacije više usmjerene na nove oblike poučavanja i vrednovanje, nego na eventualne nove teme i sadržaje. Teme (cjeline) za učitelje matematike osnovnih škola su zaključno s prosincem 2019. redom bile: $K u$ rikulumsko planiranje poučavanja u predmetu Matematika, Kurikulumi međupredmetnih tema, Kurikulumski pristup poučavanju: od ishoda do vrednovanja, Vrednovanje, Razvoj kompetencije Učiti kako učiti, Kurikulum nastavnog predmeta — razrada odgojno obrazovnih ishoda i planiranje aktivnosti, Obilježavanje Dana hrvatske glagoljice i glagoljaštva, Obilježavanje dana broja $\pi$, Osnove rada u OneNote bilježnici, Rješavanje problema $i$ Elementi vrednovanja iz kurikuluma nastavnog predmeta Matematika. Stoga je nužno planski i sadržajno educirati učitelje o novim implementiranim sadržajima. Bitno je i ne nametati to učiteljima kao dodatno vremensko opterećenje jer dodatne edukacije, bilo fizičke bilo virtualne, nisu nikako valorizirane učiteljima, niti novčano niti u pogledu smanjenja satnice ili dokidanja dijela dokumentacije koje se moglo i moralo napraviti prije nego je sama kurikularna reforma krenula kako bi se učitelji imali vremena posvetiti edukaciji.

\section{$5 \quad$ Ostvarenje sadržaja}

Od izuzetne je važnosti dobro statističko predznanje za učenike. Kako je po Odluci [1] statistika uključena od prvog razreda, potrebno je već tada tome posvetiti veliku pažnju. Kao što Čižmešija $i$ sur. [9] predlažu, potrebno je najprije krenuti od klasifikacije objekta po kriterijima (najprije 
po jednom, po dva pa onda po više kriterija). Taj redoslijed usvajanja sadržaja iz statistike je ponešto drugačiji od onog iz Odluke [1].

Primjeri moraju biti bliski učenicima. Što se jednog kriterija tiče, možemo s učenicima razvrstavati po spolu, boji kose, broju braće/sestara, žive li u stanu ili kući, dijele li s nekim sobu ili ne i slično. Nakon toga, potrebno je napraviti i obrnuto, napraviti razvstavanja pa da učenici pogađaju po kojem su kriteriju objekti razvrstani. Kriteriji mogu biti isti kao i kad su učenici sami razvrstavali, no potrebno je pripaziti da kriteriji budu očitiji (primjerice, u ovom obrnutom smjeru su bolji očiti primjeri podjele kao što su po spolu ili boji kose, nego, primjerice, po veličini cipela jer je bolje uvijek ići na općepoznate kriterije). Dobro je uključiti i brojčane i nebrojčane kriterije.

Nakon toga, lako se s učenicima provede i razvrstavanje po dva ili više kriterija, primjerice spol i duljina rukava majice, spol i boja kose, boja kose i boja očiju i slično. Svi ti primjeri su učenicima bliski te će stoga učenici biti zainteresiraniji za suradnju. Naravno, i ovdje možemo raditi u obrnutom smjeru (već razvrstano u grupe, a učenici moraju odrediti kriterije). Ako je razvrstavanje po kriterijima dobro usvojeno, onda će učenicima biti lakše usvojiti i sadržaje iz skupova, po Odluci [1] predviđene za ostvarivanje u petom razredu osnovne škole.

Prema Čižmešija i sur. [9], sljedeći korak je provođenje malog samostalnog istraživanja. Najprije treba krenuti s postavljanjem problema i planiranjem njegova rješavanja, a završiti s prikupljanjem i organiziranjem podataka. Predmet istraživanja mora biti blizak učenicima, primjerice, vole li ili ne vole određeni desert ili voće, koja im je najdraža vrsta sladoleda, kućni ljubimac i slično, ali i svi oni kriteriji koje su možda već koristili za razvrstavanje u grupe. Treba dati priliku učenicima da sami osmisle pitanja, ali i pripaziti na formulaciju, kako pitanja tako i odgovora. Primjerice, ako se učenike pita koji sladoled najviše vole, onda bi trebalo sve vrste sladoleda predvidjeti kao mogući odgovor, a ne samo vaniliju i čokoladu kao najčešće/najvjerojatnije odabire, nego i šumsko voće, jabuku, limun itd.

Što se faze prikupljanja podataka tiče, učenici ih mogu prikupljati na način da im učitelj isprinta popis učenika pa da pored imena stavljaju nekakve oznake. Budući da je još uvijek riječ o prvom razredu, odlična metoda je i tablica crtica, gdje se za svakog učenika upisuje po jedna crtica, a crtice se onda mogu pisati u grupe (primjerice po pet crtica) za lakše prebrojavanje kasnije.

\begin{tabular}{|c|c|c|}
\hline \multirow{2}{*}{ Živim u: } & kući & |||||||||| $\mid$ \\
\cline { 2 - 3 } & zgradi & |||||||||||||||| \\
\hline
\end{tabular}

Tablica 2: Primjer tablice crtica 
Što se organiziranja podataka tiče, prema Čižmeřija $i$ sur. 9 važno je početi s fizičkim grafovima. Primjerice, ako je kriterij živi li učenik u kući ili u zgradi, svaki učenik dobije figuricu kućice ili zgrade. Učenici onda te figurice mogu slagati u hrpe i uspoređivati veličine hrpa. Nakon toga, učenici dobiju papiriće (istih dimenzija) na kojima su slike kuća i zgrada. Zatim te papiriće mogu donositi na hrpe pa opet uspoređivati veličina hrpa, lijepiti papiriće na ploču u skupine, slagati u „zmije” na podu pa uspoređivati koja je zmija dulja (tu također papirići moraju biti istih dimenzija). Po broju slika kuća i zgrada mogu onda odrediti koliko učenika živi u kući, a koliko u zgradi i sami to crtati u bilježnice. U tom trenutku su naučili prikazivati podatke slikovnim dijagramima (piktogramima).

Iz piktograma je lako napraviti prijelaz na stupčaste dijagrame. Slike kuća/zgrada se poslože u „zmije” , odnosno stupce i napravi se prijelaz od slike na, primjerice, kvadratić. Onoliko kvadratića koliko je ostalo u svakoj ,zmiji”, odnosno u stupcu, predstavlja broj učenika u pojedinoj kategoriji. Kvadratić su prikladna zamjena jer ih učenici lako povežu s kvadratićima u bilježnicama, no i sve ostale zamjene su prikladne.

S učenicima je nužno cijelo vrijeme voditi diskusiju. Primjerice, što bi se dogodilo s prikazom podataka kada bi se netko od učenika preselio iz zgrade u kuću i slično. Prirodan prijelaz se $u$ tom trenutku može napraviti i prema piktogramima u kojima jedan simbol ne predstavlja samo jediničnu, nego i neku drugu vrijednost. Primjerice, slika jedne kuće ili jedan kvadratić mogu predstavljati četiri učenika. Tu s učenicima lako možemo diskutirati koliko bi učenika predstavljalo pola slike (tj. pola kvadratića), koliko četvrtina kvadratića i slično. Nakon toga, učenicima se može prezentirati nekakav piktogram koji predstavlja njihov razred, s manjim brojem slika/simbola nego što je njih u razredu pa da oni probaju odgonetnuti koliko bi učenika svaki simbol predstavljao. Tu se javlja potreba za diskusijom pitanjima kao što su „ک̌to kada ne bi znali koliko učenika ima u razredu, bi li mogli odgonetnuti koliko učenika predstavlja pojedini simbol?", a što je onda prirodan prijelaz na pojam legende dijagrama.

Učenicima je u tom trenutku dobro dati tablice u kojima su ovaj put dane i oznake redaka, ne samo stupaca pa da onda i tako mogu prikazati dobivene podatke. Kvadratiće unutar iste kategorije onda mogu obojiti jednom bojom, unutar druge kategorije kriterija drugom bojom itd. Nakon toga se lako napravi prijelaz na stupčasti dijagram micanjem simbola kvadratića. Bitno je cijelo vrijeme s učenicima provoditi diskusiju, postavljati refleksivna pitanja, ali i, primjerice, davati gotove dijagrame pa da ih oni sami interpretiraju.

Prikazivanje podataka Venn-ovim dijagramima, odnosno uvođenje Vennovih dijagrama, planirano prema Odluci [1] u petom razredu os- 
novne škole, lako možemo povezati s razvrstavanjem po dva kriterija. Primjerice, $u$ jednom krugu mogu biti dječaci iz razreda, u drugom krugu mogu biti svi učenici iz razreda koji žive u stanu (zgradi), a na presjeku krugova se onda nalaze svi dječaci koji žive u stanu (zgradi). Česta učenička pogreška je upis istog imena/člana skupa i u presjek krugova i unutar nekog od krugova (a izvan presjeka). Odlukom [1] je u petom razredu predviđena obrada pojmova podskupa, presjeka i unije skupova, no sa znatiželjnijim učenicima se lako obrađuje i pojam komplementa, iako na bazičnoj razini. Primjerice, ako promatramo samo školu, komplement 5.c razreda su svi ostali razredi unutar škole.

Prvi susret s pojmom aritmetičke sredine (prosjeka) brojčanih podataka je, prema Odluci [1, planiran u petom razredu osnovne škole. Iako je veliki dio učenika upoznat s pojmom prosjeka i bez problema usvaja njegov pojam (pogotovo ako koreliramo s računanjem prosjeka ocjena), često postoje i učenici kojima je nešto teže približiti taj pojam. Tu možemo korelirati s njima poznatim situacijama, primjerice, redarima $u$ razredu, predsjednikom razreda, završnom (srednjom) ocjenom na kraju četvrtog razreda, izborom naše pjesme za Eurosong, nogometnom reprezentacijom i slično, s ciljem približavanja najčešćem opisu arimetičke sredine (najbolji reprezentant/predstavnik niza podataka). Tada učenici puno lakše usvajaju samu tehniku računanja aritmetičke sredine.

Što se linijskog dijagrama tiče, prema Odluci [1], njegovo uvođenje je planirano u šestom razredu. Tu je jedan od prikladnih primjera kretanje srednje temperature $\mathrm{u}$ nekom mjestu po mjesecima $\mathrm{u}$ godini. Učenici mogu, u dobivene predloške, upisivati podatke te ih onda povezivati linijama. Diskusija se može razviti iz pitanja što se događa s linijom kada temperature rastu/padaju/stagniraju i obrnuto, a i korelacija s grafovima u fizici (primjerice vremena i udaljenosti) je onda puno lakša i prirodnija.

Što se pojma frekvencije (apsolutne) i relativne frekvencije tiče, učenicima je strano jedino nazivlje jer apsolutnu frekvenciju lako povežu s brojem pojavljivanja, a relativnu s postotcima (postotkom pojavljivanja).

Kod primjene i obrade svakog grafa je bitna diskusija o njegovim prednostima i manama, ali i o primjerenosti korištenja grafova za određene skupove podataka. Učenici mogu za zadaću (ili kao projekt) proučavati i ostale grafičke prikaze (dijagrame) kao što su kružni dijagram, histogram, stabljika-list dijagram, box-and-whiskers dijagram i sl., ali i kombinacije različitih dijagrama (primjerice linijski i stupčasti). Učenike je, kao što je prije spomenuto, potrebno upozoriti i na manipulacije ili nedostatne podatke na dijagramima koji ih mogu navesti na pogrešne zaključke. Od toga se također može napraviti nekakva dodatna zadaća ili mali projekt, jer barem što se projekata tiče, prema [8] nas 
zasigurno čeka njihova veća implementacija u nastavi.

\section{Literatura}

[1] Ministarstvo znanosti i obrazovanja, Odluka o donošenju kurikuluma za nastavni predmet Matematike za osnovne škole i gimnazije u Republici Hrvatskoj, Narodne novine NN 7/2019, Zagreb 2019.

[2] World Economic forum, Executive opinion survey 2017-2018, (preuzeto 6. 8. 2019.)

[3] Ministarstvo znanosti, obrazovanja i športa RH, Nacionalni okvirni kurikulum za predškolski odgoj i obrazovanje te opće obvezno i srednjoškolsko obrazovanje, Zagreb 2011.

[4] Ministarstvo znanosti, obrazovanja i športa RH, Nastavni plan i program za osnovnu školu, Zagreb 2006.

[5] A. Benček, M. Marenić, Motivacija učenika osnovne škole u nastavi matematike, Školske novine, Zagreb 2006.

[6] Infografike - Matematika, Zagreb 2015. https://www.ncvvo.hr/ medunarodna-istrazivanja/timss/ (preuzeto 8. 8. 2019.)

[7] A. Sakač, Implementacija sadržaja iz statistike u razrednu nastavu matematike, diplomski rad, Čakovec 2018.

[8] I. Nad, Anketni upitnik, https://docs.google.com/forms/ d/1WNTAxLqHb7VzVQ9Yxro_SzyG02ASRuOI7nrPRP9B11I/edit\# responses

[9] A. Čižmešija, N. Radović, T. Soucie, R. Svedrec, Igrajmo se s podatcima, Zbornik radova IV. kongresa nastavnika matematike, Hrvatsko matematičko društvo, Školska knjiga, Zagreb 2010.

Ivan Nađ

Osnovna škola „Eugena Kvaternika”, Školska 4, Velika Gorica

Visoko učilište „Algebra” , Ilica 242, Zagreb

E-mail adrese: ivan.nadjzg@gmail.com, inad@racunarstvo.hr

Zaprimljen: 14. kolovoza 2019.

Prihvaćen: 29. studenoga 2019. 